\title{
Educational Beliefs of Prospective Physical Education and Sports Teachers
}

\author{
Yunus Emre Karakaya \\ Faculty of Sports Science, Firat University, Turkey \\ E-mail: emrekarakaya@firat.edu.tr
}

Fatih Mehmet Ugurlu

Faculty of Sports Science, Firat University, Turkey

E-mail: fmugurlu@firat.edu.tr

İsmail Polatcan

School of Physical Education and Sports, Mardin Artuklu University, Turkey

E-mail: polatcan86@gmail.com

Metin Yilmaz (Corresponding author)

Faculty of Sports Science, Firat University, Turkey

E-mail: metin.yilmaz@firat.edu.tr

Tamer Karademir

Faculty of Sports Science, Kahramanmaraş Sütçü İmam University, Turkey

E-mail: tamer.karademir@hotmail.com

Received: October 20, 2021 Accepted: November 23, 2021

Published: December 1, 2021

doi:10.5296/jei.v7i2.19109 URL: https://doi.org/10.5296/jei.v7i2.19109 


\section{Abstract}

This study was conducted to reveal the educational beliefs of prospective physical education and sports teachers, who receive education at the higher education level in Turkey, according to dependent and independent variables. Within this scope, the "Educational Belief Scale" was used to collect the data from 359 prospective teachers. The data collected from the sample were first analyzed by SPSS 22.0 package software. In the correlation analysis, it was observed that the "Educational Beliefs Scale" and the progressivism subscale were correlated very strongly and positively, which was the strongest correlation in the analysis $(r=0.918 ; p<0.05)$. In the regression analysis, four different model structures were created, where it was determined that the subscale with the highest prediction power for the "Educational Beliefs Scale" was the progressivism subscale that predicted $84 \%$ of the variance of the "Educational Beliefs Scale" $\left(\mathrm{R}^{2}=0.840\right)$. In conclusion, it was discovered that the prospective teachers did not internalize the fundamentalism, which is included in the traditional educational philosophy. Significant responsibilities fall on the shoulders of academics and decision-makers to enable prospective teachers to save the valuable sections of basic information and values of the past and transfer them to new generations while approaching teaching with a perspective that promotes the potential of new generations in building a better civilization upon the achievements of past generations.

Keywords: Prospective teachers, Educational belief, Higher education, Sport

\section{Introduction}

Education is of utmost importance for philosophy to be beneficial to humanity and develop healthily. The existence of philosophy depends on education while the stance of education depends on philosophy. The contributions of philosophy to education include goal setting and development. The criteria obtained from philosophy also enable the education system to be evaluated in terms of its internal consistency. Philosophy also sets criteria for training qualified individuals while determining the perspective of individuals toward other individuals.

Educational philosophy plays numerous active roles such as determining the acquisitions of education, creating course contents, setting teaching methods and techniques, choosing assessment and evaluation tools, evaluating programs, and models of disciplines used by teachers (Aslan, 2017). Educational philosophy attempts to create novel hypotheses to be used in education while serving the aim of combining philosophical and educational approaches, such as the nature of individuals, societies, and learning, to create a wholeness. Thus, beliefs and perspectives toward education are vital mediums in determining the aims of education. These beliefs guide teachers, prospective teachers, educational politicians as well as serving a function of motivating and activating students. Therefore, the educational beliefs of teachers and prospective teachers also define their theoretical dispositions and educational practices that are chosen to be used in educational processes. Moreover, educational beliefs also possess the quality of being a variable in evaluating teaching success (Önen, 2011). Wiles and Bondi (2007) define educational philosophies as "perennialism", "fundamentalism", "progressivism", "reconstructionism" and "existentialism". Today, 
educational philosophies, such as perennialism and fundamentalism, are regarded as rather traditional educational philosophies while educational philosophies, such as progressivism and reconstructionism and existentialism, are regarded as modern educational philosophies (Çetin et al., 2012).

In the philosophy of sports, the history, anthropology, movement, and size of games, performance aspects, aesthetics, ethical and societal aspects are examined. Philosophy of sports is a field of information that constantly investigates the reality of the concept of sports and the essence of sports while interpreting and enlightening the concept with each piece of new information obtained from sports sciences and philosophies. Philosophy of sports searches answers for questions such as "What are the principles and aims of sports?", "How did sports come out?", and "What are the meaning and importance of sports?". Philosophy of sports helps those in the field of physical education and sports to understand what they are trying to achieve in a better way. It also helps those in the field of physical education and sports in recognizing and understanding the field in a better way. Philosophy of sports also facilitates overcoming problems and new encounters and making correct decisions.

Today, the profession of teaching is a field that requires specific field knowledge and skills in the social, cultural, economic, scientific, and technological fields that are related to education and professional competency. Investigating the educational beliefs of teachers, who are regarded as shareholders of education, is vital in terms of improving preservice training programs for teachers and teaching practices (Recepoğlu, 2013; Pajares, 1992). Chan and Elliott (2004) stated that teaching and learning approaches of teachers exhibited similarities with the teaching and learning perspectives of the teachers. Ornstein and Hunkins (2014) stated that individuals' lives, decisions, experiences, worldviews, attitudes, and beliefs are based on their philosophies. The perspective of teachers, their philosophical perspectives, and educational beliefs influence educational activities and processes of them both inside and outside classrooms.

\subsection{The Study Focus}

The philosophy adopted by individuals is one of the most important elements that influence their lives, ways of thinking, and behaviors. Philosophy, which is effective in every field of individuals' lives, is a field that is effective before the education process, in the education process, and after the conclusion of the education process in addition to guiding these processes. In today's world, where technology and globalization are dazzling, prospective physical education teachers are required to develop their modern and democratic way of thinking by inducing changes in their education, attitudes, and behaviors. In Turkey, changes in lifestyles, upsurge in the relationship between technology and social media in the young generation, and propagation of stationary lifestyle increased the importance of physical education and sports activities in education. Henceforth, physical education and sports teachers abandon the teacher-centered approaches and adopt student-centered and neoteric ways of teaching methods. 


\section{MlMacrothink}

\subsection{The Study Aim}

In this study, it was aimed to reveal the educational beliefs of prospective physical education and sports teachers, who receive sports education at the higher education level in Turkey, according to dependent and independent variables. It is believed that revealing the educational beliefs of prospective physical education and sports teachers will contribute to this process and the literature in the future.

\section{Method}

\subsection{The Study Group}

The sample of the study consisted of 359 randomly chosen prospective physical education and sports teachers who studied in Ahi Evran University (61 prospective teachers), Firat University (190 prospective teachers), and Gaziantep University (108 prospective teachers). The formation of the sample group from these universities was due to convenience.

\subsection{Scale Information}

The data of the sample group were collected by using the "Educational Belief Scale", which was developed by Y1lmaz et al. (2011) along with validity and reliability studies. The scale consisted of 40 items and 5 subscales. The subscales covered progressivism (13 items), existentialism ( 7 items), reconstructionism ( 7 items), perennialism (8 items), and fundamentalism (5 items).

\subsection{Data Analysis Process}

The researchers conducted the scale with 400 prospective teachers in person. Of the questionnaire forms obtained from the sample, those that were completed incorrectly or deficiently were eliminated and 359 questionnaire forms were evaluated in total. The data were entered into SPSS 22.0 package software and the normality analyses of the "Educational Belief Scale" and its subscales were first investigated. As it was presented in Table 1, it was determined that the skewness and kurtosis values of the "Educational Belief Scale" and its subscales were between +1.5 and -1.5. According to the statements of Tabachnick and Fidell (2007), who determined that skewness and kurtosis values of +1.5 and -1.5 could be interpreted as the existence of normal distribution, it was concluded that the data demonstrated a normal distribution. These results also ensured the correlation and regression analyses conducted at the end of the study. Within the scope of this study, it was observed that the Cronbach alpha coefficients were 0.93 in the subscale of progressivism, 0.91 in the existentialism subscale, 0.87 in the reconstructionism subscale, 0.80 in the perennialism subscale, and 0.78 in the fundamentalism subscale. 
Table 1. Results of normality tests of the educational belief scale and its subscales

\begin{tabular}{|l|l|l|l|l|l|}
\hline Scale & $\mathbf{N}$ & Mean & SD & Skewness & Kurtosis \\
\hline Educational Belief Scale & 359 & 3.811 & 0.724 & {$[-1.143 ; 0.129]$} & {$[1.396 ; 0.257]$} \\
\hline Progressivism & 359 & 3.878 & 0.849 & {$[-1.061 ; 0.129]$} & {$[0.902 ; 0.257]$} \\
\hline Existentialism & 359 & 3.902 & 0.894 & {$[-1.021 ; 0.129]$} & {$[0.639 ; 0.257]$} \\
\hline Reconstructionism & 359 & 3.792 & 0.810 & {$[-0.711 ; 0.129]$} & {$[0.306 ; 0.257]$} \\
\hline Perennialism & 359 & 3.869 & 0.788 & {$[-0.889 ; 0.129]$} & {$[-0.694 ; 0.257]$} \\
\hline Fundamentalism & 359 & 3.442 & 1.016 & {$[-0.480 ; 0.129]$} & {$[-0.536 ; 0.257]$} \\
\hline
\end{tabular}

Then, "Independent Samples t-test", which is one of the parametric tests, was conducted to evaluate the level of differentiation in the variable of gender, which was one of the independent variables. Additionally, "One-Way Variance Analysis", which is another parametric test, was conducted to determine the differentiation according to the grade levels of education. To reveal the relationship between dependent variables in terms of their nature and direction, "Pearson Correlation Analysis" was conducted. To explain the quality of the relationship in question in a better way and to determine the predictive aspect between the "Educational Belief Scale" and its subscales, "Multiple Regression Analysis" was conducted. The levels of the correlations between the dependent variables were evaluated according to the remarks of Kalayc1 (2006), where correlation coefficients of 0.00-0.25 are regarded as very weak correlations in addition to $0.26-0.49$ as weak correlations, $0.50-0.69$ as moderate correlations, $0.70-0.89$ as strong correlations, and $0.90-1.00$ as very strong correlations.

Another presupposition of linear regression analysis is a linear relationship between dependent and independent variables. For this data, the scatter plot graph was presented below (Figure 1). When the distribution graph of the educational belief scale was examined, it was observed that a linear and positive relationship existed, which was interpreted as the presence of a linearity assumption in the regression model. 


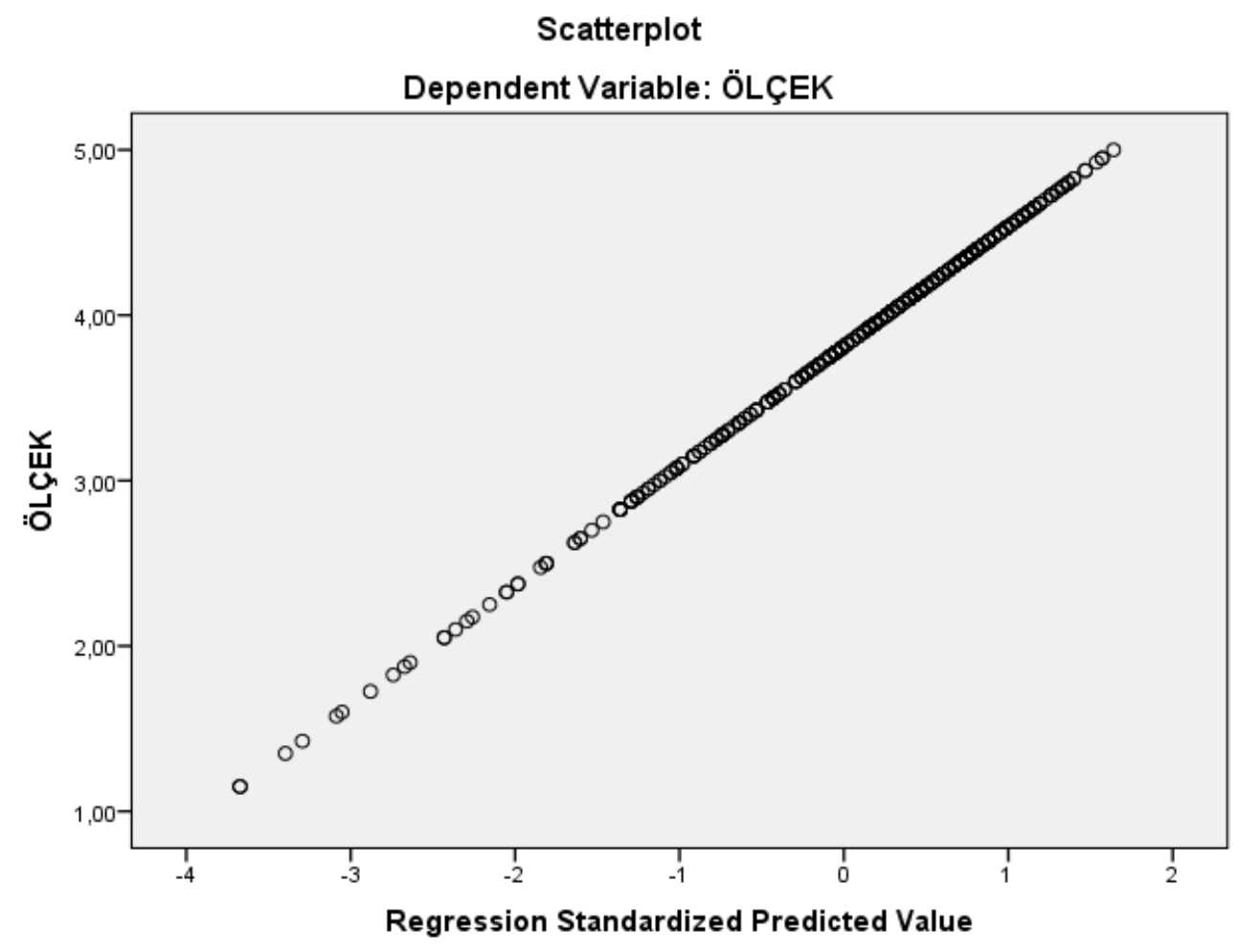

Figure 1. Scatter plot graph

Because the error terms in regression analysis are assumed to be independent of each other, the test of this assumption was conducted with the Durbin-Watson value. With this test, it was attempted to investigate whether these error terms affected each other (namely, the presence of autocorrelation). The Durbin-Watson value was examined and the results were presented below (Table 5/Model 1). Analyses were conducted to determine the contributions of each subscale in the scale stepwise and the "stepwise method" was adopted in the regression analysis. In the stepwise method, following the determination of the independent variables that could affect the dependent variables, the independent variables that affected the dependent variables the most were chosen. By starting from the strongest independent variable that met the conditions determined, the independent variables that had significant effects on dependent variables were included in the model one by one (Table 5).

\section{Results}

In line with the aims of the study, the results obtained from the beliefs of the prospective physical education and sports teachers were presented below. 
Table 2. Results of the independent samples t-test conducted to determine whether there were differences in the study group according to the variable of gender

\begin{tabular}{|c|c|c|c|c|c|c|}
\hline Scale & Gender & $\mathbf{N}$ & Mean & SD & t-Value & p-Value \\
\hline \multirow{2}{*}{ Educational Belief Scale } & Male & 254 & 3.837 & 0.672 & \multirow{2}{*}{1.071} & \multirow{2}{*}{0.285} \\
\hline & Female & 105 & 3.747 & 0.837 & & \\
\hline \multirow{2}{*}{ Progressivism } & Male & 254 & 3.911 & 0.803 & \multirow{2}{*}{1.122} & \multirow{2}{*}{0.263} \\
\hline & Female & 105 & 3.800 & 0.950 & & \\
\hline \multirow{2}{*}{ Existentialism } & Male & 254 & 3.933 & 0.843 & \multirow{2}{*}{1.026} & \multirow{2}{*}{0.306} \\
\hline & Female & 105 & 3.827 & 1.006 & & \\
\hline \multirow{2}{*}{ Reconstructionism } & Male & 254 & 3.793 & 0.769 & \multirow{2}{*}{0.033} & \multirow{2}{*}{0.974} \\
\hline & Female & 105 & 3.790 & 0.905 & & \\
\hline \multirow{2}{*}{ Perennialism } & Male & 254 & 3.904 & 0.742 & \multirow{2}{*}{1.301} & \multirow{2}{*}{0.191} \\
\hline & Female & 105 & 3.785 & 0.886 & & \\
\hline \multirow{2}{*}{ Fundamentalism } & Male & 254 & 3.468 & 0.962 & \multirow{2}{*}{0.758} & \multirow{2}{*}{0.449} \\
\hline & Female & 105 & 3.379 & 1.139 & & \\
\hline
\end{tabular}

Note. ${ }^{*} \mathrm{p}>0.05$.

In the Educational Belief Scale $(\mathrm{t}=1.071 ; \mathrm{p}=0.285)$, progressivism subscale $(\mathrm{t}=1.122 ; \mathrm{p}=$ $0.263)$, existentialism subscale $(t=1.026 ; p=0.306)$, reconstructionism subscale $(t=0.033$; $\mathrm{p}=0.974)$, perennialism subscale $(\mathrm{t}=1.301 ; \mathrm{p}=0.191)$ and fundamentalism subscale $(\mathrm{t}=$ $0.758 ; p=0.449)$, no statistically significant difference was observed $(\mathrm{p}>0.05)$ (Table 2$)$. 


\section{Macrothink}

Table 3. Results of the one-way variance analysis conducted to determine whether there were differences in the study group according to the variable of grade level

\begin{tabular}{|c|c|c|c|c|c|c|c|}
\hline \multicolumn{2}{|l|}{ Scale Grade Level } & $\mathbf{N}$ & Mean & SD & $\mathbf{F}$ & p-Value & LSD \\
\hline \multirow{4}{*}{ Educational Belief Scale } & (a) $1^{\text {st }}$ Grade & 36 & 3.976 & 0.643 & \multirow{4}{*}{8.233} & \multirow{4}{*}{$0.000 *$} & \multirow{4}{*}{$\mathrm{b}>\mathrm{a}, \mathrm{c}, \mathrm{d}$} \\
\hline & (b) $2^{\text {nd }}$ Grade & 95 & 3.508 & 0.705 & & & \\
\hline & (c) $3^{\text {rd }}$ Grade & 128 & 3.885 & 0.687 & & & \\
\hline & (d) $4^{\text {th }}$ Grade & 100 & 3.945 & 0.741 & & & \\
\hline \multirow{4}{*}{ Progressivism } & (a) $1^{\text {st }}$ Grade & 36 & 4.130 & 0.765 & \multirow{4}{*}{7.964} & \multirow{4}{*}{$<$ fF0.000* } & \multirow{4}{*}{$\mathrm{b}>\mathrm{a}, \mathrm{c}, \mathrm{d}$} \\
\hline & (b) $2^{\text {nd }}$ Grade & 95 & 3.531 & 0.860 & & & \\
\hline & (c) $3^{\text {rd }}$ Grade & 128 & 3.980 & 0.810 & & & \\
\hline & (d) $4^{\text {th }}$ Grade & 100 & 3.989 & 0.831 & & & \\
\hline \multirow{4}{*}{ Existentialism } & (a) $1^{\text {st }}$ Grade & 36 & 4.142 & 0.881 & \multirow{4}{*}{8.019} & \multirow{4}{*}{$0.000 *$} & \multirow{4}{*}{$\mathrm{b}>\mathrm{a}, \mathrm{c}, \mathrm{d}$} \\
\hline & (b) $2^{\text {nd }}$ Grade & 95 & 3.545 & 0.898 & & & \\
\hline & (c) $3^{\text {rd }}$ Grade & 128 & 3.948 & 0.861 & & & \\
\hline & (d) $4^{\text {th }}$ Grade & 100 & 4.095 & 0.845 & & & \\
\hline \multirow{4}{*}{ Reconstructionism } & (a) $1^{\text {st }}$ Grade & 36 & 3.952 & 0.795 & \multirow{4}{*}{8.965} & \multirow{4}{*}{$0.000 *$} & \multirow{4}{*}{$\mathrm{b}>\mathrm{a}, \mathrm{c}, \mathrm{d}$} \\
\hline & (b) $2^{\text {nd }}$ Grade & 95 & 3.437 & 0.831 & & & \\
\hline & (c) $3^{\text {rd }}$ Grade & 128 & 3.888 & 0.705 & & & \\
\hline & (d) $4^{\text {th }}$ Grade & 100 & 3.950 & 0.828 & & & \\
\hline \multirow{4}{*}{ Perennialism } & (a) $1^{\text {st }}$ Grade & 36 & 4.000 & 0.750 & \multirow{4}{*}{5.331} & \multirow{4}{*}{$0.001 *$} & \multirow{4}{*}{$\mathrm{b}>\mathrm{a}, \mathrm{c}, \mathrm{d}$} \\
\hline & (b) $2^{\text {nd }}$ Grade & 95 & 3.598 & 0.738 & & & \\
\hline & (c) $3^{\text {rd }}$ Grade & 128 & 3.949 & 0.783 & & & \\
\hline & (d) $4^{\text {th }}$ Grade & 100 & 3.978 & 0.803 & & & \\
\hline \multirow{4}{*}{ Fundamentalism } & (a) $1^{\text {st }}$ Grade & 36 & 3.338 & 1.086 & \multirow{4}{*}{0.865} & \multirow{4}{*}{0.459} & \multirow{4}{*}{ - } \\
\hline & (b) $2^{\text {nd }}$ Grade & 95 & 3.349 & 0.839 & & & \\
\hline & (c) $3^{\text {rd }}$ Grade & 128 & 3.445 & 1.038 & & & \\
\hline & (d) $4^{\text {th }}$ Grade & 100 & 3.564 & 1.113 & & & \\
\hline
\end{tabular}

Note. ${ }^{*} \mathrm{p}<0.05$.

In the Educational Belief Scale $(\mathrm{F}=8.233 ; \mathrm{p}=0.000)$, progressivism subscale $(\mathrm{F}=7.964 ; \mathrm{p}$ $=0.000)$, existentialism subscale $(\mathrm{F}=8.019 ; \mathrm{p}=0.000)$, reconstructionism subscale $(\mathrm{F}=$ 
8.965; $\mathrm{p}=0.000)$ and perennialism subscale $(\mathrm{F}=5.331 ; \mathrm{p}=0.001)$, statistically significant differences were observed $(\mathrm{p}<0.05)$. As a result of the LSD test conducted to determine which grades the differences existed, it was determined that the prospective physical education and sports teachers in the $2^{\text {nd }}$ grade had lower levels of educational beliefs. In the fundamentalism subscale, it was observed that there were no statistically significant differences in the educational beliefs of prospective physical education and sports teachers according to the variable of grade level $(F=0.865 ; p>0.05)$ (Table 3$)$.

Table 4. Results of correlation analysis conducted for the relationship between educational belief scale and its subscales

\begin{tabular}{|c|c|c|c|c|c|c|c|}
\hline Scale & Descriptors & 1 & 2 & 3 & 4 & 5 & 6 \\
\hline \multirow{3}{*}{ Educational Belief Scale (1) } & $\mathbf{R}$ & 1 & & & & & \\
\hline & $\mathbf{p}$ & - & & & & & \\
\hline & $\mathbf{N}$ & 359 & & & & & \\
\hline \multirow{3}{*}{ Progressivism (2) } & $\mathbf{r}$ & $0.918^{*}$ & 1 & & & & \\
\hline & $\mathbf{p}$ & 0.000 & - & & & & \\
\hline & $\mathbf{N}$ & 359 & 359 & & & & \\
\hline \multirow{3}{*}{ Existentialism (3) } & $\mathbf{r}$ & $0.894^{*}$ & $0.827^{*}$ & 1 & & & \\
\hline & $\mathbf{p}$ & 0.000 & 0.000 & - & & & \\
\hline & $\mathbf{N}$ & 359 & 359 & 359 & & & \\
\hline \multirow{3}{*}{ Reconstructionism (4) } & $\mathbf{r}$ & $0.869^{*}$ & $0.726^{* *}$ & $0.745^{*}$ & 1 & & \\
\hline & $\mathbf{p}$ & 0.000 & 0.000 & 0.000 & - & & \\
\hline & $\mathbf{N}$ & 359 & 359 & 359 & 359 & & \\
\hline \multirow{3}{*}{ Perennialism (5) } & $\mathbf{r}$ & $0.874^{*}$ & $0.718^{*}$ & $0.745^{*}$ & $0.744^{*}$ & 1 & \\
\hline & $\mathbf{p}$ & 0.000 & 0.000 & 0.000 & 0.000 & - & \\
\hline & $\mathbf{N}$ & 359 & 359 & 359 & 359 & 359 & \\
\hline \multirow{3}{*}{ Fundamentalism (6) } & $\mathbf{r}$ & $0.552^{*}$ & $0.343^{*}$ & $0.315^{*}$ & $0.423^{*}$ & $0.437^{*}$ & 1 \\
\hline & $\mathbf{p}$ & 0.000 & 0.000 & 0.000 & 0.000 & 0.000 & - \\
\hline & $\mathbf{N}$ & 359 & 359 & 359 & 359 & 359 & 359 \\
\hline
\end{tabular}

Note. ${ }^{*} \mathrm{p}<0.05$.

It was determined that the strongest correlation was between the "Educational Belief Scale" 
and the progressivism subscale $(r=0.918 ; p=0.000)$, which was a very strong and positive correlation. On the other hand, it was determined that the weakest correlation was between the perennialism subscale and the existentialism subscale $(r=0.315 ; p=0.000)$, which was a positive and weak correlation (Table 4).

Table 5. Analysis of the model structures regarding the effects of the subscales of the educational belief scale of the educational belief scale

\begin{tabular}{|c|c|c|c|c|c|c|c|}
\hline Model & Independent Variable & B & $\mathbf{t}$ & $\mathbf{p}$ & $\mathbf{F}$ & Model (p) & $\mathbf{R}^{2}$ \\
\hline Model 1 & $\begin{array}{l}\text { Constant } \\
\text { Progressivism }\end{array}$ & $\begin{array}{l}- \\
0.918\end{array}$ & $\begin{array}{l}10.896 \\
43.720\end{array}$ & $\begin{array}{l}0.000 \\
0.000\end{array}$ & 1911.458 & 0.000 & 0.843 \\
\hline Model 2 & $\begin{array}{l}\text { Constant } \\
\text { Progressivism } \\
\text { Perennialism }\end{array}$ & $\begin{array}{l}- \\
0.599 \\
0.444\end{array}$ & $\begin{array}{l}4.997 \\
31.701 \\
23.489\end{array}$ & $\begin{array}{l}0.000 \\
0.000 \\
0.000\end{array}$ & 2706.031 & 0.000 & 0.938 \\
\hline Model 3 & $\begin{array}{l}\text { Constant } \\
\text { Progressivism } \\
\text { Perennialism } \\
\text { Reconstructionism }\end{array}$ & $\begin{array}{l}- \\
0.488 \\
0.315 \\
0.280\end{array}$ & $\begin{array}{l}3.353 \\
32.341 \\
20.273 \\
17.816\end{array}$ & $\begin{array}{l}0.001 \\
0.000 \\
0.000 \\
0.000\end{array}$ & 3513.184 & 0.000 & 0.967 \\
\hline Model 4 & $\begin{array}{l}\text { Constant } \\
\text { Progressivism } \\
\text { Perennialism } \\
\text { Reconstructionism } \\
\text { Fundamentalism }\end{array}$ & $\begin{array}{l}- \\
0.494 \\
0.268 \\
0.242 \\
0.163\end{array}$ & $\begin{array}{l}0.086 \\
54.466 \\
28.217 \\
25.350 \\
25.140\end{array}$ & $\begin{array}{l}0.931 \\
0.000 \\
0.000 \\
0.000 \\
0.000\end{array}$ & 7476.304 & 0.000 & 0.988 \\
\hline
\end{tabular}

Note. ${ }^{*} \mathrm{R}=0.918 ;$ Durbin-Watson $=0.904 ; \mathrm{p}<0.000$ level relationship.

With the stepwise regression model, five independent variables were included in the model one by one and four different models were created (Table 5). In Model 1, the F value was 1911.458 and the level of significance was 0.000 while in Model 2, the F value was 2706.031 and the level of significance was 0.000. Furthermore, in Model 3, the F value was 3513.184 and the level of significance was 0.000 while in Model 4, the F value was 7476.304 and the level of significance was 0.000 . Accordingly, it was observed that there was a significant difference between mean values of variables while the model, as a whole, was significant at every level. With the variance analysis ( $\mathrm{F}$ test), whether the entirety of the model was significant was concluded. In the t-test, the significance of the variables was examined $(5 \%$ significance level) and it was determined that each subscale was significant within the model. As it can be seen in Model 1, the progressivism subscale predicts $84 \%$ of the variance in the "Educational Belief Scale" $\left(\mathrm{R}^{2}=0.843\right)$. According to the t-test, the progressivism subscale 
was observed to be significant with a constant value $(p<0.001)$. When the model that was created between the progressivism subscale and the "Educational Belief Scale" was examined as a whole, it was determined that the model was significant $(F=1911.458 ; p<0.001)$. When the Durbin-Watson coefficient was examined, the determined value of 0.918 could be regarded as an agreeable value. In other words, the progressivism subscale affected the "Educational Belief Scale" $(\beta=0.918)$. In Model 2, progressivism and perennialism subscales were included in the analysis, and the prediction power of these two subscales on the "Educational Belief Scale" reached to $93 \%\left(\mathrm{R}^{2}=0.938\right)$. In Model 3, it was observed that progressivism, perennialism, and reconstructionism subscales' prediction power of the "Educational Belief Scale" reached $96 \%\left(\mathrm{R}^{2}=0.967\right)$. In Model 4, it was determined that the subscales of progressivism, perennialism, reconstructionism, and fundamentalism reached a prediction power of $98 \%$ for the "Educational Belief Scale" $\left(\mathrm{R}^{2}=0.988\right)$. Finally, as a result of these four models, it was determined that the subscale with the highest prediction power of the "Educational Belief Scale" was the progressivism subscale (Model 1).

\section{Discussion}

The results obtained within the scope of the study were evaluated in this section. In the sample group, no significant difference was determined between the genders (Table 2). However, it was observed that the beliefs of male prospective physical education and sports teachers were at higher levels compared to female prospective teachers. It could be stated that prospective teachers adopted both modern educational philosophy (progressivism, existentialism, and reconstructionism) and traditional educational philosophies (perennialism and fundamentalism). When previous studies were evaluated, similar conclusions with this study were observed (Berkant \& Özaslan, 2019; Aslan, 2017; Uğurlu \& Çalmaşur, 2017; Yokuş, 2016; Çelik \& Orçan, 2016; Alkın et al., 2014; Biçer et al., 2013; Ilgaz et al., 2013; Çetin et al., 2012). In a study conducted by Beytekin and Kadı (2015), it was concluded that male prospective teachers had higher scores in beliefs regarding traditional educational philosophies while female prospective teachers had higher scores in modern educational philosophies. In both traditional and modern educational philosophies, it was observed that male prospective teachers had higher scores. In a study conducted by Aslan \& Aybek (2017), no significant difference was observed in the beliefs of modern education philosophy between male and female prospective teachers. However, significant differences were observed in the beliefs regarding traditional educational philosophy.

Within the scope of the study, significant differences were observed between prospective physical education and sports teachers according to the variable of grade level (Table 3). It was determined that there were significant differences in the Educational Belief Scale, progressivism, existentialism, reconstructionism, and perennialism subscales between the prospective physical education and sports teachers study in the $2^{\text {nd }}$ grade and prospective teachers studying in other grades. The educational beliefs of prospective physical education and sports teachers studying in $2^{\text {nd }}$ grade were less positive compared to prospective teachers studying in other grades. In the fundamentalism subscale, no significant difference was determined. It was observed that the educational beliefs of prospective physical education and sports teachers studying in $2^{\text {nd }}$ grade decreased in $2^{\text {nd }}$ grade while entering into a recovery 
process in $4^{\text {th }}$ grade with the sports education they received. This could be explained by the fact that the philosophical perspectives and beliefs could be affected due to rather general courses included in the first year of undergraduate education while practical lessons increase in the final years in addition to opportunities of practices in real schools (internship activities). When previous studies in the literature were examined, the following results were obtained. In a study conducted by Çetin et al. (2012), it was observed that grade levels had statistically significant effects on prospective teachers' levels of adopting traditional and modern educational philosophies. In a study conducted by Ekiz (2007), it was determined that the educational beliefs of prospective teachers studying in $1^{\text {st }}$ grade in terms of adopting modern educational philosophies were higher compared to prospective teachers who studied in other grade levels. It was also observed that prospective teachers who studied in $1^{\text {st }}$ grade advocated for perennialism traditional philosophy of education more compared to prospective teachers studying in $4^{\text {th }}$ grade while the prospective teachers in $4^{\text {th }}$ grade advocated for modern educational philosophies of progressivism and reconstructionism compared to prospective students in $1^{\text {st }}$ grade. In a study conducted by Çakmak et al. (2016), differences were determined in the perennialism subscale according to grade level while no difference was observed in other subscales. It was determined that the educational beliefs of scores of prospective teachers decreased in $2^{\text {nd }}$ grade and increased in $4^{\text {th }}$ grade, which was based on education. In a study conducted by Özbaş (2015), philosophical perspectives of prospective teachers were examined longitudinally and it was determined that idealism and realism scores were increased from $1^{\text {st }}$ grade to $4^{\text {th }}$ grade while perennialism, experimentalism and existentialism scores were decreased. In a study conducted by Alkın et al. (2014), it was determined that prospective teachers in lower grade levels adopted traditional educational philosophies more while prospective teachers in higher grade levels adopted modern educational philosophies more. Several studies concluded that grade levels of prospective teachers did not have any significant effect on their educational beliefs (Kozikoğlu \& Erden, 2018; Kaymakamoğlu, 2017).

In the correlation analysis conducted within the scope of the study, it was observed that the strongest correlation was between the "Educational Belief Scale" and progressivism subscale, which was a very strong and positive correlation. Additionally, it was observed that the weakest correlation was between existentialism and fundamentalism subscales, which was a weak and positive correlation (Table 4). In student-centered educational systems, it is believed that students' higher beliefs of progressivism are a normal construct. When it is considered that the basis of progressivism includes a student-centered perspective, it was observed that these results were expected and the educational beliefs of prospective teachers were consistent with the contents of the education they adopted. Within this framework, in a study conducted by Yazıcı (2017), it was determined that the most commonly preferred educational beliefs of prospective teachers were existentialism and progressivism. In a study conducted by Aslan and Aybek (2017), it was emphasized that prospective teachers adopted modern educational philosophies (progressivism, existentialism, and reconstructionism) more. In a study conducted by Baş (2015), it was determined that there were strong and moderate levels of significant correlations between educational philosophy beliefs and teaching-learning perspectives of teachers. It was also stated that there were significant 
positive correlations between teachers' educational beliefs of progressivism, reconstructionism, and existentialism, and constructivist teaching-learning perspectives. Additionally, the perennialism and fundamentalism educational philosophy beliefs of teachers were significantly and positively correlated with traditional teaching-learning perspectives. In a study conducted by Çetin et al. (2012), it was observed that prospective teachers adopted traditional educational philosophies (perennialism and fundamentalism) more. Furthermore, several studies reported that prospective teachers adopted the educational philosophy of progressivism in the first place (Görmez, 2015; Çalışkan, 2013; Duman, 2008).

As a result of the regression analysis, it was determined that progressivism, perennialism, reconstructionism, and fundamentalism subscales' prediction power of the "Educational Belief Scale" was 98\%. It was also observed that the highest prediction power for the "Educational Belief Scale" belonged to the progressivism subscale (Table 5). The fact that students who adopted the educational beliefs of progressivism were inclined to a subject-centered approach could indicate that the main features of teacher training programs should be emphasized further in education where the characteristics of students are considered rather than the features of subjects. It is believed that the prospective physical education and sports teachers believed in modern educational philosophical movements due to their education and the free and selective environment of sports. Additionally, it was predicted that prospective teachers were drawn to a student-centered approach and as a result, they would practice innovative, ever-developing, objective, and flexible teaching methods. In studies conducted within the framework of the study, it was observed that prospective teachers adopted fundamentalism the least (Kahramanoğlu \& Özbakış, 2018; Hayırsever \& Oğuz, 2017; Çelik \& Orçan, 2016; Tunca et al., 2015; Yılmaz \& Tosun, 2013). In a study conducted by Alkin et al. (2014), it was observed that prospective teachers respectively adopted existentialism, progressivism, reconstructionism, perennialism, and fundamentalism the most. In a study conducted by Biçer et al. (2013), it was stated that prospective teachers adopted progressivism the most while adopting fundamentalism the least.

In Turkey, the Turkish Education System included in the National Education Fundamental Law No. 1739 predicts that a progressivist and pragmatist educational philosophy should be adopted (Üstüner, 2008). Within the scope of the study, the educational beliefs of prospective teachers are coherent with both the Turkish Education System and philosophies of physical education and sports teaching departments. The fact that the beliefs of prospective physical education teachers, who will implement the program, and the physical education and sports teachers who actively practice the program are coherent with the philosophy of the education system and program are deemed positive in terms of educational practices. When it is considered that the educational beliefs of prospective teachers, who are future teachers, will shape future practices, this result has vital importance. Opportunities of prospective physical education and sports teachers to practice modern educational perspectives and ideal teaching practices, which soared in recent years, in undergraduate lessons and the fact that they did not meet with a real classroom environment yet could lead them to adopt traditional educational philosophies (perennialism and fundamentalism) less. 


\section{Conclusions and Implications}

When the results of the study were evaluated generally, the following results were obtained. It was determined that the educational beliefs of prospective physical education and sports teachers included higher levels of modern philosophical movements (progressivism, existentialism, and reconstructionism). It was predicted that prospective physical education and sports teachers who adopt a student-centered approach with advanced emotional intelligence, who are humanitarian, democratic, and who possess the ability to empathize while keeping away from strict and rigid discipline mentality would conduct their lessons with modern approaches while teaching. The beliefs of prospective physical education and sports teachers toward modern educational philosophy are coherent with the sports education they receive. They also internalized perennialism, which is included in the traditional educational philosophy. However, it was observed that prospective teachers could not internalize fundamentalism. Accordingly, significant responsibilities fall on the shoulders of academics and decision-makers to enable prospective teachers to save the valuable sections of basic information and values of the past and transfer them to new generations while approaching teaching with a perspective that promotes the potential of new generations in building a better civilization upon the achievements of past generations. This is because the nature of learning includes working hard and pressure mostly. In education and teaching, the initiative should be in the teacher rather than students. Nature and subject of the education process should be internalized splendidly. It is of importance for the educational philosophies adopted by prospective physical education and sports teachers and the educational philosophies which constitute the foundation of the education system and program to be coherent. Therefore, all of the courses provided for prospective physical education and sports teachers should be shaped on these philosophical bases. In educational philosophy lessons that are included in the educational curriculum of prospective physical education and sports teachers, it can be ensured that students think about the reflections of every philosophy on education and conduct practices. In conclusion, in addition to this study, it is suggested that studies should be conducted with prospective physical education and sports teachers and physical education and sports teachers who received education with different curriculums. By adopting various techniques of research, such as observation, the coherences can be investigated by comparing the educational beliefs of physical education and sports teachers/prospective teachers and their practices in courses. Because physical education and sports lessons are mainly a practical lesson, studies can be conducted on educational beliefs of physical education and sports teachers by using interview and observation techniques. Studies should also be conducted with academics who prepare prospective physical education and sports teachers for the profession.

\section{Acknowledgements}

The ethical committee information of this research is as follows:

- The Issuing University: Firat University;

- $\quad$ Meeting Date: February 27, 2020; 
- Number of Meetings: 05;

- Decision No: 2.

\section{References}

Alkın-Şahin, S., Tunca, N., \& Ulubey, Ö. (2014). The relationship between pre-service teachers' educational beliefs and their critical thinking tendencies. Illkögretim Online, 13(4), 1473-1492. https://doi.org/10.17051/io.2014.56482

Aslan, S. (2017). An investigation of the educational beliefs of primary school teachers in terms of several variables. Kastamonu Education Journal, 25(4), 1453-1468.

Aslan, S., \& Aybek, B. (2017). An investigation of educational philosophies adopted and critical thinking disposition in terms of various variables. Gaziantep University Journal of Social Sciences, 16(2), 373-385. https://doi.org/10.21547/jss.281737

Baş, G. (2015). Correlation between teachers' philosophy of education beliefs and their teaching-learning. Education and Science, 40(182), 111-126. https://doi.org/10.15390/EB. 2015.4811

Berkant, H. G., \& Özaslan, D. (2019). Exploring prospective teachers' educational beliefs in terms of various variables. Eskişehir Osmangazi Üniversitesi Sosyal Bilimler Dergisi, 20, 1-18. https://doi.org/10.17494/ogusbd.555081

Beytekin, F. O., \& Kad1, A. (2015). A study on the values and educational beliefs of student teachers. The Journal of Academic Social Science Studies, 31, 327-341. https://doi.org/ 10.9761/JASSS2658

Biçer, B., Er, H., \& Özel, A. (2013). The relationship between the epistemological beliefs and educational philosophies of the teacher candidates adopted. Journal of Theory and Practice in Education, 9(3), 229-242.

Çakmak, Z., Bulut, B., \& Taşkıran, C. (2016). A study on the opinions of social studies field pre-service teachers on educational beliefs. Abant İzzet Baysal Üniversitesi Ĕ̈itim Fakültesi Dergisi, 16(Special Issue II), 1190-1205.

Çalışkan, İ. (2013). A study about preservice science teachers' educational psychology approaches and planning processes. Hacettepe University, Journal of Education, 1(Special Issue), 68-83.

Çelik, R., \& Orçan, F. (2016). A study on prospective teachers' educational beliefs. Journal of Theory and Practice in Education, 12(1), 63-77.

Çetin, B., İlhan, M., \& Arslan, S. (2012). An investigation of educational philosophies adopted by prospective teachers in terms of various variables. The Journal of Academic Social Science Studies, 5(5), 149-170._https://doi.org/10.9761/jasss_134

Chan, K. W., \& Elliott, R. G. (2004). Relational analysis of personal epistemology and conceptions about teaching and learning. Teaching and Teacher Education, 20, 817-831. 
https://doi.org/10.1016/j.tate.2004.09.002

Duman, B. (2008). Comparisons of educational philosophies adopted and the learning strategies and learning styles used by students. Çukurova Universitesi Sosyal Bilimler Enstitüsü Dergisi, 17(1), 203-224.

Ekiz, D. (2007). An investigation of student-teachers' views of educational philosophies from the angle of different teacher education programs. Ondokuz Mayı Üniversitesi Eğitim Fakültesi Dergisi, 24, 1-12.

Görmez, S. (2015). Determination of teacher candidates and school teachers' philosophical of education and examination environment of education (Master thesis, Gazi Üniversitesi, Turkey).

Hayırsever, F., \& Oğuz, E. (2017). Effects of teacher candidates' educational beliefs on their critical thinking tendencies. Abant İzzet Baysal Üniversitesi Ĕ̈itim Fakültesi Dergisi, 17(2), 757-778. https://doi.org/10.17240/aibuefd.2017.17.30227-326596

Ilgaz, G., Bülbül, T., \& Çuhadar, C. (2013). Investigation of the relationship between preservice teachers' educational beliefs and their perceptions of self-efficacy. Abant İzet Baysal Üniversitesi Eğitim Fakültesi Dergisi, 13(1), 50-65.

Kahramanoğlu, R., \& Özbakış, G. (2018). The determination of classroom teachers educational and epistemological beliefs and the examination of relationship between each other. Journal of Interdisciplinary Educational Research, 2(3), 8-27.

Kalayc1, Ş. (2006). SPSS uygulamalı çok değişkenli istatistik teknikleri (Translation: SPSS applied multivariate statistical techniques). Asil Yayıncılık.

Kaymakamoğlu, E. S. (2017). Self-efficacy beliefs of special education student teachers: implications for teacher training programs. International Journal of Humanities and Education, 3(2), 209-221.

Kozikoğlu, İ., \& Erden, R. Z. (2018). The investigation of the relationship between pre-service teachers' opinions concerning critical pedagogy and beliefs of educational philosophies. Elementary School Online, 17(3), 1566-1582. http://doi.org/10.17051/ilkonline. 2018.466392

Önen, A. S. (2011). The effect of candidate teachers' educational and epistemological beliefs on professional attitudes. Hacettepe University, Journal of Education, 41, 293-301.

Ornstein, A. C., \& Hunkins, F. P. (2014). Curriculum: Foundations, principles, and issues. Eğitim Kitapevi.

Özbaş, Ç. B. (2015). The examine of philosophical preferences of pre-service social studies teachers' during teacher education. Türkiye Sosyal Araştırmalar Dergisi, 19(1), 117-138.

Pajares, F. M. (1992). Teachers' beliefs and educational research: Cleaning up a messy construct. Review of Educational Research, 62(3), 307-332. https://doi.org/10.2307/1170741 


\section{Macrothink}

Recepoğlu, E. (2013). Analyzing the relationship between prospective teachers' life satisfaction and attitudes concerning teaching profession. Hacettepe University, Journal of Education, 1(Special Issue), 311-326.

Tabachnick, B. G., \& Fidell, L. S. (2007). Using multivariate statistics. Pearson Education.

Tunca, N., Şahin, A. S., \& Oğuz, A. (2015). The relationship between teachers' educational beliefs and professional values. Kalem Eğitim ve Ínsan Bilimleri Dergisi, 5(1), 11-47. http://doi.org/10.23863/kalem.2017.43

Uğurlu, C. T., \& Çalmaşur, H. (2017). A comparative study of educatıonal beliefs of teachers and teacher candidates: A mixed method study. Adlyaman Üniversitesi Sosyal Bilimler Enstitüsü Dergisi, 9(25), 230-273.

Üstüner, M. (2008). The comparison of the educational philosophies of Turkish primary school superintendents and teachers. Eurasian Journal of Educational Research, 33, 177-192.

Wiles, J., \& Bondi, J. (2007). Curriculum development: A guide to practice. Pearson Merill Orentice Hall Inc.

Yazıcı, T. (2017). Educational philosophy beliefs of music teacher candidates. Kastamonu Education Journal, 25(2), 1-16.

Y1lmaz, K., \& Tosun, M. F. (2013). Relationship between teachers' educational belief and their views about teacher-student relationships. Journal of Research in Education and Teaching, 2(4), 205-218.

Y1lmaz, K., Altınkurt, Y., \& Çokluk, Ö. (2011). Developing the educational belief scale: the validity and reliability study. Educational Sciences: Theory \& Practice, 11 (1), 343-350.

Yokuş, T. (2016). An examination of philosophy of education music teacher candidates adopt in terms of different variables. Muğla Sitkı Koçman University, Journal of Education, 3(1), 26-36. https://doi.org/10.21666/mskuefd.59611

\section{Copyright Disclaimer}

Copyright for this article is retained by the author(s), with first publication rights granted to the journal.

This is an open-access article distributed under the terms and conditions of the Creative Commons Attribution license (http://creativecommons.org/licenses/by/3.0/). 